\title{
PERSONALITY AND JOB OUTCOMES: MEDIATION OF ETHICAL IDEOLOGY
}

\author{
Rudsada Kaewsaeng-on ${ }^{1}$, Tariq Iqbal Khan ${ }^{2 *}$, Abdul Zahid Khan ${ }^{3}$ \\ ${ }^{1}$ Faculty of Humanities and Social Sciences, Prince of Songkla University, Thailand; ${ }^{2 *}$ Research Fellow, Prince of \\ Songkla University, Thailand; ${ }^{3}$ Faculty of Management Sciences, International Islamic University, Islamabad, Pakistan. \\ Email: ${ }^{1}$ rudsada.k@psu.ac.th, ${ }^{2 *}$ tariqfirst@gmail.com, ${ }^{3}$ zahidkhan.fms@iiu.edu.pk
}

Article History: Received on $30^{\text {th }}$ March 2020, Revised on $24^{\text {th }}$ May 2020, Published on $22^{\text {nd }}$ June 2020

\begin{abstract}
Purpose: This study aims to theorize new conceptual linkages between two popular paradigms of management research personality (Big Five Trait) and ethics (Ethical Ideology). Big Five personality traits and ethical ideology dimensions (idealism and relativism) relationship with job outcomes such as interpersonal conflict, workplace deviance, and Organizational Citizenship Behavior (OCB) were proposed.

Methodology: This study adopted a longitudinal field survey design. Data analysis for descriptive, regression, and correlation techniques, was done using SPSS v 17 whereas conduct Confirmatory Factor Analysis (CFA) of study variables was done using AMOS v 16.

Main Findings: Results revealed significant association of i) extraversion, conscientiousness, and agreeableness with $\mathrm{OCB}$, ii) Agreeableness and neuroticism with workplace deviance and iii) agreeableness, openness to experience, neuroticism with interpersonal conflict. Moreover, agreeableness was a significant predictor of idealism ethical ideology, neuroticism and openness to experience were significant predictors of relativism ethical ideology. Idealism significantly predicted interpersonal conflict and OCB and relativism significantly predicted workplace deviance and interpersonal conflict. Idealism ethical ideology mediated between extraversion and interpersonal conflict, agreeableness and interpersonal conflict as well as OCB. On the other hand, relativism ethical ideology mediated between openness to experience and interpersonal conflict. Similarly, relativism also mediated between neuroticism and two job outcomes (interpersonal conflict, workplace deviance).
\end{abstract}

Limitations/ Applications: Future research directions and implications for theory and practice are suggested.

Novelty/Originality of this study: This study explained the conceptual mechanism that individual outcomes of the Big Five traits are determined through the ethical ideology of the respective personality trait; moreover, this study also added empirical evidence in existing OB literature from a unique cultural context i.e., Pakistan.

Keywords: Personality, Job Outcomes, Mediation, Ethical, Ideology.

\section{INTRODUCTION}

The influence of personality traits on employees behaviour has remained an issue of debate among the leading scholars (Epstein\& O'Brien, 1985). The debate is among the proponents of the situational versus trait approaches. The scholars have focused on the impact of the Big Five personality traits on job performance (Barrick1991), job satisfaction (Judge, Heller, \& Mount, 2002), job stress (Lannu\&Nobleza, 2017, Penley\&Tomaka, 2002), intent to leave (Mobley, Griffeth, Hand, \&Meglino, 1979), Customer Relationship Management (Haq, Ramay, Rehman\& Jam, 2010), OCB (Barrick, Parks, \& Mount, 2005) and workplace deviance (Judge et al, 2002). The wide use of personality in placement decisions has gathered the attention of organization behaviour scholars to focus more on the personality trait research (Raja\& Johns, 2010). On the other hand, an individual's ethical ideology is a significant factor that determines the behaviour of the individual at the workplace. Research on ethics has long studied moral philosophies based on which people get involved in ethically prescribed/allowed behaviours (Kohlberg, 1983, 1984). Ethical ideology refers to "a system of ethics used to make moral judgments, which offer guidelines for judging and resolving behaviour that may be ethically questionable". Considering this important role of ethical ideologies in the determination of individual behaviour, every individual has some ethical ideology and have some types of personality traits simultaneously. There is a paucity of research in personality literature discussing the ethical ideology or ethical philosophy of the Big Five personality traits. The theorized and tested the expected relationships between the Big five traits and ethical dimensions predicting that which personality traits will have what type of ethical ideology among two independent dimensions of Forsyth's (1980, 1992) model, which are "idealism" and "relativism" and their ultimate impact on organizational and personal outcomes.

The former studies stressed to find out the mechanism by which personality traits impact job outcomes (Ameer, 2017, Chang, Rosen, \& Levy, 2009; Raja, Johns \&Ntalianis, 2004). This study also attempted to explain the conceptual mechanism that individual outcomes of the Big Five traits are determined through the ethical ideology of the respective personality trait. The study hypothesized and tested direct relationships as well as the mediation of ethical ideology between the Big Five personality traits and job outcomes such as OCB, Interpersonal conflict, and workplace deviance. The reason for the selection of all three outcomes is that these are the common behaviours associated with ethical conduct at the workplace. Both the ideologies (idealism and relativism) talk about ethics and following general moral 
rules. So interpersonal conflict, interpersonal workplace deviance and OCB focused toward individuals (OCBI) are considered as dependent variables in this study.

Another major contribution of this research is to add empirical evidence in existing OB literature from a unique cultural context. According to (Hofsted, 1980) Pakistan was ranked 14th having a highly collectivist culture. Generally, the study related to ethics and personality is very rare and specifically, these kinds of research attempts in collectivist Eastern contexts are hard to be seen in management literature. Testing of theories developed in a western context in such a unique context is recommended by the scholars in the field (Abbas, Raja, Darr\&Bouckenooghe, 2012; Tsui, Nifadkar, $\underline{\& \mathrm{Ou}, 2007)}$, responding to this call for further investigations makes this study a valuable contribution in literature.

\section{Research Gap and Objectives of the Study}

The studies investigating such a group of outcomes in a single study are very rare in personality research. Specifically, in eastern context (Abbas et al., 2012). Existing research emphasizes on investigating the mechanisms by which personality traits impact the job outcomes (Ameer, 2017, Chang, Rosen, \& Levy, 2009). This study is an answer to the calls of these researchers and attempts to explain the conceptual mechanism that individual outcomes of the Big Five traits are determined through the ethical ideology of the respective personality trait. The objectives of this study are:

- To identify the relationship between Big Five personality traits and outcomes (OCB, interpersonal conflict, workplace deviance).

- To identify the relationship between ethical ideology and outcomes (OCB, interpersonal conflict, workplace deviance).

- To identify the relationship between ethical ideology and the Big Five personality traits.

- To identify the mediation of ethical ideology between Big Five personality traits and outcomes (OCB, interpersonal conflict, workplace deviance).

\section{LITERATURE REVIEW AND HYPOTHESES}

\section{Big Five and Job Outcomes}

\section{Extraversion and Job Outcomes}

Extraversion is one of the important personality types that are associated with friendliness, warmth, affection, energetic, and optimism. Research has reported a weaker relationship between extraversion and deviant behaviours (Jude et al., 2002). Evidence predicted the chances of getting involved in corruption and dishonesty are less in the case of extravert individuals (Antara, Musa, Hassan, 2016; Sackett\&Wanek, 1996). Since these individuals have an instinct of friendliness and warmth, they are less likely to be engaged in workplace deviance and interpersonal conflict.

Due to their friendly nature and social networking skills, these individuals are confident, brave, energetic, and significant in their relationships (Goldberg, 1992). According to Organ (1988), OCBs are discretionary behaviours which are neither sanctioned nor formally rewarded by the organization. These individuals are highly sociable, have leadership abilities and are active in social circles (Rogosch\&Cicchetti, 2004). Consequently, the subsequent hypothesis is developed.

H1: Extraversion will be positively related to OCB, and negatively related to interpersonal conflict and workplace deviance.

\section{Conscientiousness and Job Outcomes}

Conscientious individuals possess narrow traits like being neatness, prompt, careful, vigilant, self- disciplined, and trusted. Conscientious individuals can achieve their part of the work with the least misunderstanding (Bizon, 2016; Morgeson, Reider, \& Campion, 2005). According to Organ and Ryan (1995), conscientious individuals have the most significant relationship with extra-role behaviours. According to Spector and Fox (2002), these individuals are least likely to be involved in the workplace deviance. Moreover, conscientious individuals are highly satisfied with their jobs and have a high level of morale at work (Colbert, Mount, Harter, Witt, \&Barrick, 2004), are dependable and trusted. Hence, it could be reasonable to expect that these persons are less likely to be engaged in workplace deviance and interpersonal conflicts. These individuals can inspire themselves by achieving goals and take no notice of social support and physical rewards (Costa\& McCrae, 1992). Because of their rule-following and goal-focused nature, these individuals less likely to be involved in deviant behaviours and interpersonal conflicts. Based on the above literature the hypothesis developed is as follows.

H2: Conscientiousness will be positively related to $\mathrm{OCB}$, and negatively related to interpersonal conflict and workplace deviance.

\section{Agreeableness and Job Outcomes}

This type of personality is normally associated with trust, straightforwardness, generosity, and sympathetic 
(Costa\&Widiger, 1994). The people, who score low on agreeableness, are more likely to be engaged in counterproductive behaviour (Hough, 1992; Hough, Eaton, Dunnette, Kamp, \&McCloy, 1990; Ones, Viswesvaran, \& Schmidt, 1993; Salgado, 2002). Agreeableness is negatively related with the counterproductive behaviour (Costa \& McCrae, 1992; Graziano\& Eisenberg, 1997; Wiggins, 1991; Wiggins\&Trapnell, 1996; Wiggins\&Trobst, 1999), and agreeable individuals are concerned with others' welfare (Ashton\& Lee,2001).

People who score high on agreeableness are very friendly, responsive, good nature, supportive, cooperative, and polite (Barrick\& Mount, 1991; Witt, Burke, Barrick\& Mount, 2002). In organizational settings, agreeable individuals display an advanced level of interpersonal aptitude (Witt et al., 2002). Thus, some characteristics of OCB and agreeableness are similar like helping others, altruism and people orientation. Agreeable individuals are more likely to be engaged in OCB. Based on the above literature the hypothesis proposed is as follows.

H3: Agreeableness will be positively related to OCB and negatively related to interpersonal conflict and workplace deviance.

\section{Openness to Experience and Job Outcomes}

Another personality trait is the openness to experience which is associated with characteristics of imagination, interest in art and beauty, willingness to try new things, intellectually curious, and argumentative (Costa \&Widiger, 1994). Studies argue that low openness to experience people is very narrow-minded. People who score low on openness by nature are largely involved in the workplace deviance (Goldberg, 2000). Openness to experience has a slight effect on job satisfaction so it becomes one of the predictors to increase the deviance at the workplace (Judge et al., 2002). Individuals high on openness to experience are reported to be associated with interpersonal conflict at the individual level. Individuals high on openness to experience are described as original, interested, and thoughtful (Hofsteed, DeRaad, \& Goldberg, 1992). The following hypothesis is proposed based on literature.

H4: Openness to experience will be positively related to workplace deviance, interpersonal conflict, and negatively related OCB.

\section{Neuroticism and Job Outcomes}

A neurotic personality trait is associated with anxiety, hostility, and low self-esteem, poor coping to stress, hopelessness, and tense (Costa \&Widiger, 1994). These people lost their temper frequently and get involve in humiliating behaviour. Neuroticism Personality traits heavily influenced by less emotional stability, therefore, they use harsh language and intimidate others while they perceive anything negative in them. Hence, they tend to involve more likely interpersonal deviance (Judge et al., 2002). As neurotic individuals lack this emotional stability and security, they are least likely to exhibit OCB (Barrick et al, 2005). Due to their lack of confidence and felt insecurity, neurotic individuals are reluctant to help others and go the extra mile for the organization. The people who score high on neuroticism are least likely to be engaged in social behaviours on the job such as organizational citizenship behaviour. The following hypothesis is proposed based on literature.

H5: Neuroticism will be positively related to interpersonal conflict, workplace deviance, and negatively related to OC.

\section{Big Five and Ethical Ideology}

\section{Extraversion and Ethical Ideology}

Individuals with high extraversion behaviour are considered to be friendly, lively in nature, and confident (Goldberg,1992). These individual prefer to work with other individuals (Zhang, 2002)

Characteristics of such individuals usually include friendly behaviour (Berings, Fruyt\&Bouwen, 2002), a positive attitude (Watson\& Clark, 1997) and networking skills based on positive emotions (Costa \&Widiger, 1994). Based on these characteristics, Forsyth (1992) explained that chance of extraverts to believe in idealistic ethical ideology is comparatively low. Based on these arguments the hypothesis proposed is given below;

H6: Extraversion personality will be positively related to idealism.

\section{Conscientiousness and Ethical Ideology}

According to the characteristics of conscientious personality, individuals are capable, goal-oriented, effective, selfdisciplined, and principled (Costa \&Widiger, 1994). Their need for social support is low and they hard-working (Costa \& McCrae, 1992). Their ability to focus on their skills and capabilities help them in focusing on goals on their own instead of caring for others. The expectation to believe in relativism ethical ideology is higher for the individual those scores high on conscientiousness. So based on the above literature and arguments, the hypotheses proposed as given below.

H7: Conscientiousness personality will be positively related to relativism. 


\section{Agreeableness and Ethical Ideology}

As per the characteristics of agreeableness, people are credulous, frank, selfless, sympathetic, and ingenious (Costa \&Widiger, 1994). These individuals are friendly and cool minded (Mount, Barrick, \& Strauss, 1999). Witt, Kacmar, Carlson and Zinusnaka, (2002) argued that individuals with high on agreeableness, prefer collaborative and corporatism instead of just relying on their competence. Due to all these characteristics, agreeable people are more likely to believe in idealistic ethical ideology as they are trusting, sympathetic, and avoid harming others. Predictably, people counting high on agreeableness are expected to believe in idealism ethical ideology. So based on the above literature and arguments, the subsequent hypotheses are proposed.

H8: Agreeableness personality will be positively related to idealism.

\section{Openness to Experience and Ethical Ideology}

People having their unique stance regarding the ongoing situation and possess argumentative traits, develop their patterns and code of conduct while deciding their actions. These individuals usually first conceptualize situations, processes and decision consequences before developing their code of conduct. However, they usually don't negotiation on their work persuasion and well-known patterns. Based on these characteristics, these individuals may adopt an ethical perspective relate to their work patterns (Barrick\& Mount, 1991; Cebeci, 2016). Based on the literature and discussion the hypothesis generated is as follows;

H9: Openness to experience personality will be positively related to relativism.

\section{Neuroticism and Ethical Ideology}

Individuals high on neuroticism are more expected to hostility and anger (Watson\& Clark, 1984). Due to this hostility and feeling of negative emotions and expression; it is expected that neurotic individuals will be more likely to believe in relativism then idealism. It is believed that high scoring individuals on neuroticism tend to be certain of on relativism more likely. Based on the above argument hypothesis proposed is as follows.

H10: Neuroticism personality will be positively related to relativism.

\section{Ethical Ideology and Job Outcomes}

Forsyth (1980) called for more empirical research to determine the predictive validity of ethical ideology with moral behaviour. In response to this call, Henle et al. (2005) investigated to examine the affiliation between ethical ideology and workplace deviance. The results of their study revealed a negative relationship between workplace deviance and idealism. Previous ethics research reported that idealistic individuals believe in the ethic of caring, which means harming other people is self-centered and morally wrong (Gilligan,1982). If we see the definition of workplace deviance it is defined as voluntary actions diverted towards violation of interpersonal and organizational norms (Robinson\& Bennett,1995). By looking at this definition it may be easily predicted that violation of interpersonal norms may be to humiliate, insult others and it is harmful to individuals not matching with the idealistic perspective of avoiding harming others in all circumstances. So highly idealistic individuals are least likely to be engaged in interpersonal deviance.

Since interpersonal conflicts, at times, may be associated with unethical behaviours, individuals may handle conflicts by being engaged in unethical behaviours (Grover, 1997). According to Finn, Chonko, and Hunt (1988), managers in organizations can decrease the ethically conflicting practices by enhancing individuals' ethical ideologies. It is said that idealistic individuals" "optimistically assume that desired outcomes can be obtained by engaging in moral actions" (Henle et al., 2005, p. 220) and always seek to "produce positive consequences that benefit all involved" (Forsyth, 1992, p. 462). Additionally, idealistic individuals are considered as individuals with an ethic of caring (Gilligan, 1982). These characteristics help us to speculate that idealistic individuals may be inclined towards caring for others and hence may not likely be engaged in interpersonal conflict. Consequently, the following hypothesis is developed.

H11: Idealism will be positively related to $\mathrm{OCB}$ and negatively related to interpersonal conflict and workplace deviance.

Ethical ideology is referred to as the "extent to which people reject or accept global moral rules" (Forsyth, 1992). Idealism and relativism are the two main dimensions of ethical ideology (Forsyth, 1992). Idealistic ideology is related to the belief that in any circumstances welfare of the people may not be harmed and relativistic ideology is related to the belief that following universal ethical rules and regulations is dependent on the situation and maybe violated as per individual needs (Forsyth, 1992). According to Robinson and Bennett (1995), the workplace deviance is "voluntary actions that violate policies or organizational norms and threaten the well-being of the individuals of the organization". Individuals fluctuate in their choice to contribute to workplace deviance depending on their ethical ideology ( $\underline{\text { Henle at }}$ el., 2005).

Relativist individuals vary from situation to situation in adopting ethical rules. Their attitude to switch from one ethical standard to the other based on existing and future situations. Therefore, their contradictory standards create conflicts 
with other individuals. People are indulged more in conflicts when they have dual ethical standards while treating others at the workplace. Relativist people may incline to harm others for their interest, therefore, harming a tendency plunges them into interpersonal conflict easily. Based on the aforementioned literature, I hypothesized that

H12: Relativism will be positively related to workplace deviance and interpersonal conflict and negatively related to OCB.

\section{Mediation of Ethical Ideology between Big Five and Employee Outcomes}

Considering this important role of ethical ideologies in the determination of individual behaviour, every individual has some ethical ideology and having some type of personality trait simultaneously. There is a paucity of research in personality literature discussing the ethical ideology or ethical philosophy of the Big Five personality traits. Based on Forsyth's $(1980,1992)$, personal moral philosophy model, this study is going to propose logical relationships between the Big Five traits and their ethical ideologies. This study will try to theorize to which specific personality trait will have what type of ethical ideology amongst the two independent dimensions of Forsyth's (1980, 1992), model, which are "idealism" and "relativism".

Previously the researchers aimed to analyze the way personality traits influence the job outcomes (Chang et al., 2009; Raja et al., 2004). Most of the research in the Big Five domain is concerned with determination, personality traits and impact on job outcomes. The reason behind pitching ethical ideology as a significant tool through which personality traits are linked to outcomes such as workplace deviance, OCB and interpersonal conflict is the suggestion by Henle et al (2005), in which they concluded that "ethical ideology may be an important mechanism through which organizations can determine which employee will engage in socially disproved The following" ( $p, 227)$. Following hypothesis is generated based on the above discussion;

H13: Idealism mediates the relationship between extraversion and job outcomes such as workplace deviance, OCB and interpersonal conflict.

One the other hand conscientious personality traits are effective, capable, principled, goal-oriented and self-disciplined (Costa \&Widiger, 1994; Tsai, \& Tsai, 2017). According to the nature of this trait, these people are more attracted to relativist ethical ideology, which beliefs in following or not following ethical rules based on current situations and varies accordingly. As they are more goals oriented, they may decide to follow the international ethical standards or reject them based on their contribution towards the achievement of their goals. Thus, the outcomes of conscientiousness personality will be determined through relativistic ethical ideology such as OCB, workplace deviance and interpersonal conflict. Following hypothesis is generated based on the above discussion.

H14: Idealism mediates the relationship between conscientiousness and job outcomes such as workplace deviance, $\mathrm{OCB}$ and interpersonal conflict.

The third major trait in Big Five taxonomy is agreeableness which has the characteristics: trusting and frank, ingenuous, considerate and sympathetic (Costa, \&Widiger, 1994). Individuals that are high on agreeableness will always avoid hurting others (Goldberg, 2000) and usually are friendly and unselfish towards other individuals (Ones et al., 2003). As per the nature of this personality trait, this trait is associated with idealism ideology which beliefs in not doing any act which may harm other's interests. All outcomes of agreeableness will be determined via idealism and this idealism ethical ideology is the reason why agreeable people are trusting, caring, and friendly and work for the welfare of others. Their outcomes such as workplace deviance, interpersonal conflict and OCB are determined through their idealistic ethical ideology. The following hypothesis is generated based on the above discussion.

H15: Idealism mediates the relationship between agreeableness and job outcomes such as workplace deviance, OCB, and interpersonal conflict.

The fourth important trait in the Big Five taxonomy is an openness to experience (Costa \&Widiger, 1994). As per the nature of this trait, openness to experience is related to relativistic ethical ideology. Relativism ethical ideology believes on following or not following ethical rules and it varies according to the situation. As they are more creative and imaginative so they are non- confirming to routine matters, rules and regulations. Thus, the outcomes of this personality trait will be determined through relativistic ethical ideology such as OCB, workplace deviance and interpersonal conflict. Following hypothesis is generated based on the above discussion.

H16: Relativism mediates the relationship between openness to experience and job outcomes such as workplace deviance, OCB and interpersonal conflict.

The fifth important factor in the Big Five model of personality is neuroticism (Costa \&Widiger, 1994). These are people with high confusion and face many crises such as negative sentiments, anxiety, depression and low self-esteem (Judge et al., 1993). As per the nature of this trait, neuroticism is related to relativistic ethical ideology. Relativism ethical ideology believes on following or not following ethical rules and it varies according to situations. As they are low in emotional stability, confused and have an attraction towards negative stimuli, they may believe in rejecting or accepting ethical norms as per their negative perception about environment and job. Thus, the outcomes of neurotic 
personality will be determined through relativistic ethical ideology such as OCB, workplace deviance and interpersonal conflict. Following hypothesis is generated based on the above discussion.

H17: Relativism mediates the relationship between neuroticism and job outcomes such as workplace deviance, OCB and interpersonal conflict.

\section{METHODOLOGY}

\section{Research Design \& Study Context}

The nature of the study is longitudinal field study and most of the studies conducted in such frames are adopting survey as their research and data collection techniques. So this study adopted a longitudinal field survey design. Considering the nature of the model under analysis such as personality and ethical ideology the survey seemed to be a suitable technique of assessment.

\section{Sample and Data Collection}

This study targeted the faculty and staff working in (private \& public sector) higher education institutions of Pakistan and Thailand. Big Five personality traits, ethical ideology, OCB, workplace deviance and interpersonal conflict are the variables under investigation for this research. From 07 private and public higher education institutions of Pakistan and Thailand data was gathered. A total number of 406 full-time employees and faculty members were used to collect data via a self-administered questionnaire. Since the English language is the official language so the questionnaire was developed in the English language. Convenience and quota-based sampling techniques were applied. First, the population was distributed in the public and private sector than 250 participants were taken from each sector. Data were gathered on two different periods referred to as T1 and T2. On T1 the Big five personality traits were considered then after 3 months on T2 the remaining variable (relativism, idealism, ethical ideology and employee outcomes) were assessed.

Data analysis for descriptive, regression, and correlation techniques, was done using SPSS v 17 whereas conduct Confirmatory Factor Analysis (CFA) of study variables was done using AMOS v 16.

\section{Measures}

\section{Big Five-Personality Measure}

The Big Five Inventory (BFI) scale of 44-item (John \&Srivastava 1999) was used to measure the personality traits of respondents. For extraversion (E) and neuroticism (N), 8 items were used, 9 items for each agreeableness (A) and conscientiousness (C), and openness to experience (O) 10 items were used. Items were rated on 5 points Likert scale " $1=$ strongly disagree to 5 = strongly agree". CFA was conducted for all five traits and results provided a good fit for each latent model.

A higher score means higher levels of traits.

A mediocre fit was observed in the results of factor analysis for Extraversion. The values are $\chi^{2}=15.3$, df $=4$; comparative fit index $[\mathrm{CFI}]=0.98$, goodness of fit index $[\mathrm{GFI}]=0.99$, incremental fit index $[\mathrm{IFI}]=0.98$, normed fit index $[\mathrm{NFI}]=0.98$, and root mean square error of approximation $[\mathrm{RMSEA}]=0.08$ ). The mean alpha reliability for extraversion was $(\alpha=.70)$.

A good fit for a single factor model was observed in the results of factor analysis for conscientiousness $\left({ }_{l}^{2}=9.2, d f=4\right.$; $\mathrm{CFI}=0.99, \mathrm{GFI}=0.99$, IFI $=0.99, \mathrm{NFI}=0.98$, and RMSEA $=0.05)$. The mean alpha reliability for conscientiousness was $(\alpha=.73)$.

A good fit for a single factor model was observed in the results of factor analysis for $\left({ }^{2}=5.2, d f=3\right.$; CFI $=0.99$, GFI $=$ $0.99, \mathrm{IFI}=0.99, \mathrm{NFI}=0.99$, and RMSEA $=0.04)$. The mean alpha reliability for agreeableness was $(\alpha=.72)$.

A good fit for a single factor model was observed in the results of factor analysis for Openness to experience $\left(_{l}^{2}=17.4\right.$, $d f=7 ; \mathrm{CFI}=0.99, \mathrm{GFI}=0.99, \mathrm{IFI}=0.99, \mathrm{NFI}=0.98$, and $\mathrm{RMSEA}=0.06$ ). The mean alpha reliability for openness to experience was $(\alpha=70)$.

A good fit for a single factor model was analyzed for Neuroticism's results of factor analysis $\left({ }_{l}^{2}=2.6, d f=2 ; \mathrm{CFI}=0.99\right.$, $\mathrm{GFI}=0.99$, IFI $=0.99, \mathrm{NFI}=0.99$, and RMSEA $=0.02)$. The mean alpha reliability for neuroticism was $(\alpha=.70)$.

\section{Ethical Ideology}

Forsyth (1980) 20 item scale was used to measure ethical ideology. 10 items for each idealism and relativism were used. 9-point Likert scale "9 = completely agree and $1=$ completely disagree" was used to measure responses.

Factor analysis results for both idealism $\left({ }_{\chi} 2=9.1, \mathrm{df}=4\right.$; CFI $=0.99$, GFI $=0.99$, IFI $=0.99$, NFI $=0.99$, and RMSEA $=$ $0.05)$ and relativism $(\chi 2=2.4, \mathrm{df}=1 ; \mathrm{CFI}=0.99, \mathrm{GFI}=0.99, \mathrm{IFI}=0.99, \mathrm{NFI}=0.99$, and $\mathrm{RMSEA}=0.06)$ revealed a good fit for a single factor model. 
The mean alpha reliability for idealism was $(\alpha=.84)$ while for relativism the value was $(\alpha=.83)$.

\section{OCB}

7-item measure by Williams and Anderson (1991) was adapted to measure OCB. Due to the nature of the study, only OCBI was measured. 5-point Likert scale " $1=$ never or seldom" to " 5 = will always or almost always" was used to measure responses. The results of factor analysis revealed a good fit for a single factor model $\left({ }_{l}^{2}=2.4, d f=1 ; \mathrm{CFI}=0.99\right.$, $\mathrm{GFI}=0.99$, IFI $=0.99, \mathrm{NFI}=0.99$, and RMSEA $=0.06)$. The mean alpha reliability for OCB was $(\alpha=.83)$.

\section{Interpersonal Conflict}

4-item scale (Spector \&Jex, 1998) was used to measure interpersonal conflict. Reponses were rated on 5-point likert scale " $1=$ never" to " $5=$ a lot". Factor analyses results predicted a good fit for a single factor model $\left({ }_{l}^{2}=2.4, d f=1 ;\right.$ CFI $=0.99, \mathrm{GFI}=0.99, \mathrm{IFI}=0.99, \mathrm{NFI}=0.99$, and RMSEA $=0.06)$. The mean alpha reliability was $(\alpha=.83)$.

\section{Control Variable}

To analyze control variables one-way ANOVA statistics was used. Based on evaluation four demographic variables namely age $(\mathrm{F}=5.29, \mathrm{p}<0.001)$, job nature $(\mathrm{F}=8.31, \mathrm{p}<0.001)$, total experience $(\mathrm{F}=4.18, \mathrm{p}<0.001)$, and income $(\mathrm{F}$ $=14.20, \mathrm{p}<0.001)$ significantly impacted idealism and relativism. So, these were considered as controlled variables for analyses. The results for remaining variables were not significant.

\section{RESULTS}

\section{Correlation analysis}

Reliability coefficients, mean and standard deviation results are presented in Table 1. While correlation values are presented in table 2. All zero-order bivariate correlations supported the predicted hypothesis in the preceding section.

Table 1: Descriptive Statistics

\begin{tabular}{lcccccc}
\hline S. No & Variables & $\mathbf{N}$ & Minimum & Maximum & Mean & S D \\
\hline 1 & Organization & 406 & 1 & 7 & 4.11 & 1.81 \\
\hline 2 & Gender & 406 & 1 & 2 & 1.24 & 0.42 \\
\hline 3 & Age & 406 & 22 & 60 & 28.70 & 6.73 \\
\hline 4 & Designation & 406 & 1 & 5 & 1.71 & 1.05 \\
\hline 5 & Tenure & 406 & 0.08 & 24 & 2.14 & 3.18 \\
\hline 6 & T. Experience & 406 & 0.08 & 29 & 4.52 & 5.5 \\
\hline 7 & Qualification & 406 & 3 & 5 & 4.18 & 0.62 \\
\hline 8 & Job Nature & 406 & 1 & 5 & 3.26 & 1.47 \\
\hline 9 & Income & 406 & 1 & 5 & 1.76 & 1.08 \\
\hline 10 & Extraversion & 406 & 1.75 & 4.75 & 3.40 & 0.62 \\
\hline 11 & Agreeableness & 406 & 2.11 & 4.67 & 3.62 & 0.53 \\
\hline 12 & Conscientiousness & 406 & 2.67 & 5 & 3.70 & 0.51 \\
\hline 13 & Neuroticism & 406 & 1.25 & 4.75 & 2.85 & 0.65 \\
\hline 14 & Openness to Experience & 406 & 2.3 & 5 & 3.48 & 0.5 \\
\hline 15 & Idealism & 406 & 2.7 & 9 & 6.68 & 1.38 \\
\hline 16 & Relativism & 406 & 2.5 & 9 & 5.69 & 1.45 \\
\hline 17 & IPC & 406 & 1 & 4.5 & 2.61 & 0.78 \\
\hline 18 & Deviance & 406 & 1 & 4.05 & 1.75 & 0.68 \\
\hline 19 & OCB & 406 & 2.57 & 4.57 & 3.85 & 0.39 \\
\hline & Valid N (listwise) & 406 & & & & \\
\hline
\end{tabular}

Table 2: correlation values

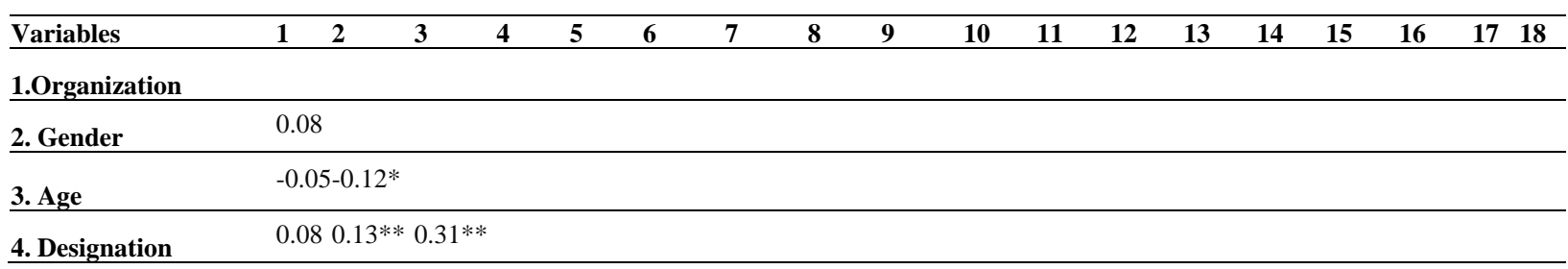




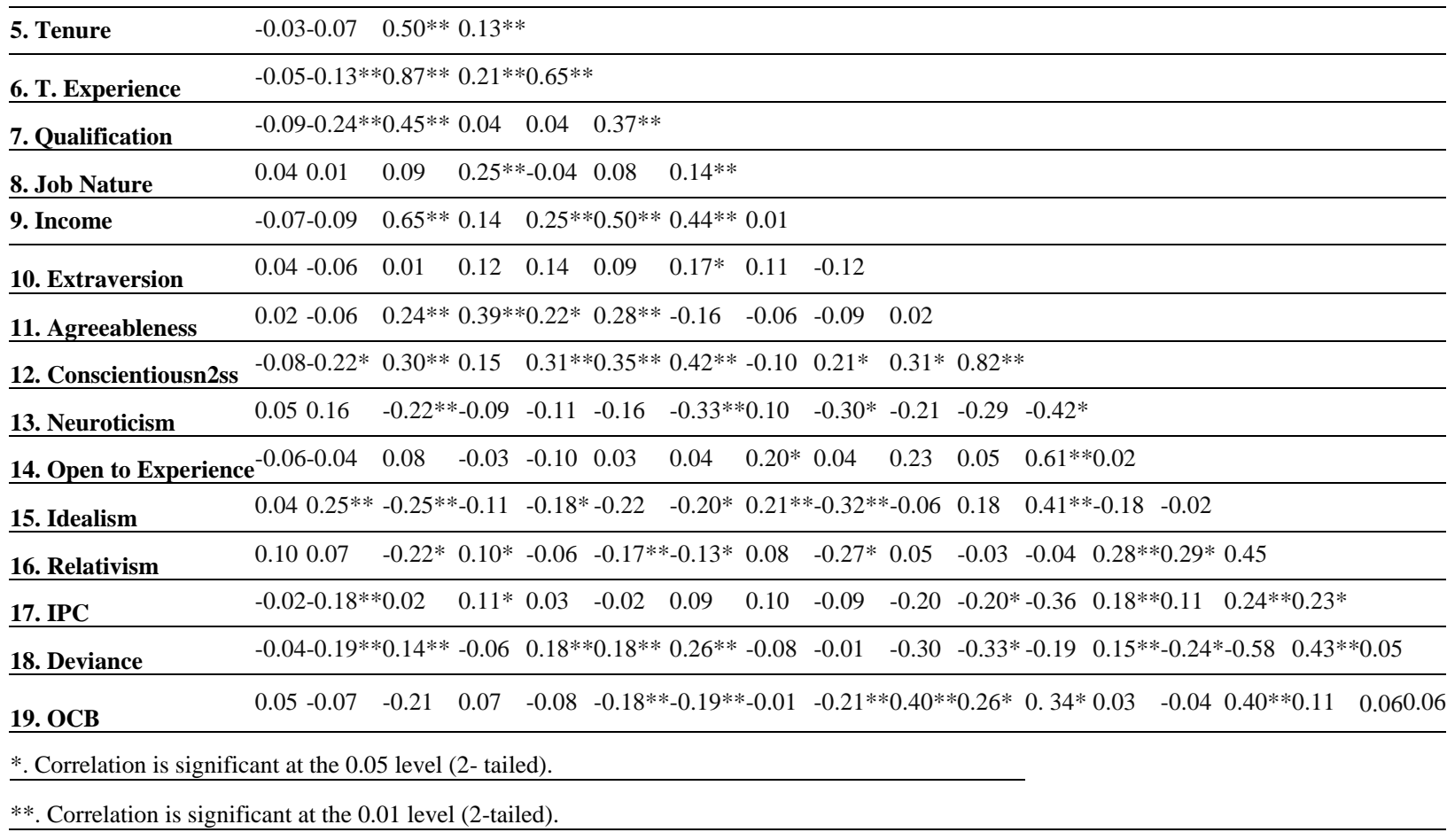

\section{Regression Analysis}

\section{Big Five Personality Traits and JobOutcomes}

Table 3 shows the Regression analysis for the study's independent variable i.e., Big Five personality types and job outcomes i.e. interpersonal conflict, workplace deviance and OCB.

Table 3: Regression Results for Big Five and Job Outcomes

\begin{tabular}{clllllllll}
\hline & IPC & \multicolumn{9}{c}{ DEVIANCE } & \multicolumn{2}{c}{ OCB } \\
\hline $\begin{array}{c}\text { Predictors } \\
\begin{array}{c}\text { Step 1 } \\
\text { Control Variables } \\
\text { Step 2 }\end{array}\end{array}$ & $\mathbf{B}$ & $\mathbf{R}$ & $\Delta \mathbf{R}^{2}$ & $\boldsymbol{\beta}$ & $\mathbf{R}$ & $\Delta \mathbf{R}^{2}$ & $\boldsymbol{\beta}$ & $\mathbf{R}$ & $\Delta \mathbf{R}^{2}$ \\
\hline Extraversion & -0.385 & 0.48 & 0.105 & -0.228 & 0.56 & 0.04 & $0.42^{* *}$ & 0.302 & 0.126 \\
\hline Agreeableness & $.491^{* * *}$ & 0.245 & 0.201 & $0.46^{* * *}$ & 0.52 & 0.18 & $0.261^{*}$ & 0.34 & 0.06 \\
\hline Conscientiousness & -0.384 & 0.46 & 0.07 & -0.18 & 0.47 & 0.02 & $0.354^{*}$ & 0.21 & 0.06 \\
\hline Neuroticism & $0.180^{*}$ & 0.69 & 0.03 & $0.162^{* *}$ & 0.157 & 0.025 & -0.272 & 0.104 & 0.06 \\
\hline $\begin{array}{c}\text { Openness to } \\
\text { Experience }\end{array}$ & $0.243^{*}$ & 0.314 & 0.04 & 0.12 & 0.13 & 0.01 & -0.275 & 0.165 & 0.05 \\
\hline
\end{tabular}

*. Correlation is significant at the 0.05 level (2- tailed). **. Correlation is significant at the 0.01 level (2-tailed).

First, a regression analysis of personality types and job outcomes is discussed. Regression analysis revealed significant positive relationship between Extraversion personality type and OCB $(B=.42, p<.01$, ) with overall variance explained $(R=.30)$ and the change in variance due to extraversion $\left(\Delta R^{2}=.13, p<0.05\right)$. This shows that $13 \%$ variance in OCB accounted for only due to the effect of extraversion personality traits. The regression results of conscientiousness personality type reflected a positive relationship with OCB $(\beta=.35, p<.05)$ with overall variance explained $(R=.21)$ and the change in variance due to conscientiousness $\left(\Delta R^{2}=.06, p<0.05\right)$. The regression results of agreeableness personality type reflected a positive relationship with OCB $(\beta=.26, p<.05)$ with overall variance explained $(R=.34)$ and the change in variance due to extraversion $\left(\Delta R^{2}=.06, p<0.05\right)$. While negative relationship was found between agreeableness and interpersonal conflict $(\beta=-.49, p<.001)$ with overall variance explained $(R=.26)$ and the change in variance due to extraversion $\left(\Delta R^{2}=.20, p<0.001\right)$. This shows that a $20 \%$ variance in OCB accounted for only due to the effect of conscientiousness personality traits. Regression results showed a positive significant relationship between openness to experience personality and interpersonal conflict $(\beta=.24, p<.05)$ with overall variance explained $\left(R^{2}=.31\right)$ and the change in variance due to extraversion $\left(\Delta R^{2}=.04, p<0.05\right)$. Regression results showed a positive significant relationship between neuroticism personality and interpersonal conflict $(B=.18, p<.05)$ with overall variance explained $\left(R^{2}=.69\right)$ and the change in variance due to neuroticism $\left(\Delta R^{2}=.03, p<0.05\right)$. Similarly, a positive significant 
relationship between neuroticism personality and workplace deviance $(\beta=.16, p<.05)$ with overall variance explained $(R=.15)$ and the change in variance due to neuroticism $\left(\Delta R^{2}=.03, p<0.05\right)$.

\section{Big Five Personality Traits and Ethical Ideology Dimensions}

Regression results of Big Five personality traits and ethical ideology dimensions reveal that extraversion did not predict idealism and conscientiousness did not predict relativism ethical ideology dimension. So this study results did not confirm the study hypothesis 6,7 .

While regression results in table 4 showed a positive significant relationship between agreeableness and idealism $(\beta=$ $.43, p<.01)$ with overall variance explained $\left(R^{2}=.51\right)$ and the change in variance due to agreeableness $\left(\Delta R^{2}=.15, p<\right.$ $0.01)$.

Regression results showed a positive significant relationship between openness to experience personality and relativism $(\beta=.29, p<.05)$ with overall variance explained $\left(R^{2}=.45\right)$ and the change in variance due to openness to experience $\left(\Delta R^{2}\right.$ $=.06, p<0.05)$. Similarly, a positive significant relationship between neuroticism personality and relativism ethical ideology dimension $(\beta=.28, p<.05)$ with overall variance explained $\left(R^{2}=.12\right)$ and the change in variance due to neuroticism $\left(\Delta R^{2}=.07, p<0.05\right)$.

Table 4: Regression Results of Big Five Traits and Ethical Ideology Dimensions

\begin{tabular}{cclllll}
\hline & Idealism & \multicolumn{3}{c}{ Relativism } & \\
\hline Predictors & $\boldsymbol{\beta}$ & $\mathbf{R}$ & $\Delta \mathbf{R}^{\mathbf{2}}$ & $\mathbf{B}$ & $\mathbf{R}$ & $\Delta \mathbf{R}^{\mathbf{2}}$ \\
\hline Step 1 & & & & & \\
\hline Control Variables & & 0.03 & & & \\
\hline Step 2 & & & & & \\
\hline Extraversion & -0.334 & 0.121 & 0.08 & & \\
\hline Agreeableness & $0.435^{* *}$ & 0.512 & 0.158 & & 0.1 & 0.02 \\
\hline Conscientiousness & & & & -0.15 & 0.121 & 0.07 \\
\hline Neuroticism & & & & $0.292^{*}$ & 0.121 & \\
\hline Openness to & & & & $0.296^{*}$ & 0.45 & 0.06 \\
\hline Experience & & & & & &
\end{tabular}

*. Correlation is significant at the 0.05 level (2- tailed).

**. Correlation is significant at the 0.01 level (2- tailed).

\section{Ethical Ideology Dimensions and Job Outcomes}

The regression results of idealism ethical ideology dimension in table 5 reflected a positive relationship with OCB ( $(\beta=$ $.41, p<.001)$ with overall variance explained $(R=.23)$ and the change in variance due to idealism $\left(\Delta R^{2}=.14, p<0.01\right)$. The regression results of idealism ethical ideology dimension reflected a positive relationship with IPC $(B=.25, p<.05)$ with overall variance explained $(R=.40)$ and the change in variance due to idealism $\left(\Delta R^{2}=.06, p<0.05\right)$. The regression results of relativism ethical ideology dimension reflected a positive relationship with IPC $(\beta=.23, p<.05)$ with overall variance explained $(R=.34)$ and the change in variance due to relativism $\left(\Delta R^{2}=.05, p<0.05\right)$. Similarly, a positive relationship with workplace deviance $(\beta=.43, p<.001)$ with overall variance explained $\left(R^{2}=.47\right)$ and the change in variance due to relativism $\left(\Delta R^{2}=.18, p<0.001\right)$.

Table 5: Regression Results for Ethical Ideology Dimensions and Job Outcomes

\begin{tabular}{lccccccccc}
\hline & IPC & \multicolumn{9}{c}{ DEVIANCE } & \multicolumn{3}{c}{ OCB } \\
\hline Predictors & $\boldsymbol{\beta}$ & $\mathbf{R}$ & $\Delta \mathbf{R}^{\mathbf{2}}$ & $\boldsymbol{\beta}$ & $\mathbf{R}$ & $\Delta \mathbf{R}^{\mathbf{2}}$ & $\mathbf{B}$ & $\mathbf{R}$ & $\Delta \mathbf{R}^{\mathbf{2}}$ \\
\hline $\begin{array}{l}\text { Step 1 } \\
\text { Control Variables }\end{array}$ & & & & & & & & & \\
\hline $\begin{array}{l}\text { Step 2 } \\
\text { Idealism }\end{array}$ & 0.028 & & & 0.028 & & & 0.028 \\
\hline Relativism & $0.256^{*}$ & 0.403 & 0.06 & -0.547 & 0.281 & 0.25 & $*$ & 0.234 & 0.143 \\
\hline
\end{tabular}

*. Correlation is significant at the 0.05 level (2-tailed). **. Correlation is significant at the 0.01 level (2-tailed).

\section{Mediation Analysis}

As shown in table 6 the lower portion explains the mediation results comprehensively. Idealism's ethical ideology fully mediated the relationship between extraversion personality trait and interpersonal conflict to provide partial support for the study hypothesis 13 . While for the other two outcomes this mediation was not proved due to not fulfilling (Baron and Kenny, 1986) criteria of testing mediation. It can be observed from results that the main effect of extraversion with 
interpersonal conflict was $(\beta=.38, p<.01)$ with overall variance explained $(R=.48)$ and the change in variance due to extraversion $\left(\Delta R^{2}=.11, p<0.01\right)$. In mediation analysis after controlling for mediator this main effect decreased to $(\beta=$ $.23, n s)$ with decreased overall variance up to $(R=.38)$ and remained to change in variance accounted only $\left(\Delta R^{2}=.03\right.$, $n s) 3 \%$ due to extraversion.

Table 6: Mediation Analysis of Ethical Ideology between Big Five and Job Outcomes

\begin{tabular}{|c|c|c|c|c|c|c|c|c|c|}
\hline \multicolumn{4}{|c|}{ IPC } & \multicolumn{3}{|c|}{ DEVIANCE } & \multicolumn{3}{|l|}{ OCB } \\
\hline Predictors & $\beta$ & $\mathbf{R}^{2}$ & $\Delta \mathbf{R}^{2}$ & $\beta$ & $\mathbf{R}^{2}$ & $\Delta \mathbf{R}^{2}$ & $\beta$ & $\mathbf{R}^{2}$ & $\Delta \mathbf{R}^{2}$ \\
\hline $\begin{array}{l}\text { Main Effects of Big Fiv } \\
\text { Step } 1\end{array}$ & & & & & & & & & \\
\hline Control Variables & & 0.025 & & & 0.023 & & & 0.035 & \\
\hline $\begin{array}{l}\text { Step } 2 \\
\text { Extraversion }\end{array}$ & $0.385^{* *}$ & 0.48 & 0.105 & -0.228 & 0.56 & 0.04 & $0.42 * *$ & 0.302 & 0.126 \\
\hline Agreeableness & $0491 * * *$ & 0.245 & 0.201 & $0.46^{* * * *}$ & 0.52 & 0.18 & $0.261 *$ & 0.34 & 0.06 \\
\hline Conscientiousness & -0.384 & 0.46 & 0.07 & -0.18 & 0.47 & 0.02 & $0.354 *$ & 0.21 & 0.06 \\
\hline Neuroticism & $0.180 *$ & 0.69 & 0.03 & $0.162 * *$ & 0.157 & 0.025 & -0.272 & 0.104 & 0.06 \\
\hline Openness to Experience & $0.243^{*}$ & 0.314 & 0.04 & 0.12 & 0.13 & 0.01 & -0.275 & 0.165 & 0.05 \\
\hline
\end{tabular}

Mediation of Ethical
Ideology
Step 1
Control Variables

\begin{tabular}{|c|c|c|c|c|c|c|c|c|c|}
\hline Control Variables & & 0.028 & & & 0.028 & & & 0.028 & \\
\hline $\begin{array}{l}\text { Step } 2 \\
\text { Idealism }\end{array}$ & $0.256^{*}$ & 0.403 & 0.06 & 0.547 & 0.281 & 0.25 & $0.412 * *$ & 0.234 & 0.143 \\
\hline Relativism & $0.234 *$ & 0.346 & 0.052 & $0.434 * * *$ & 0.471 & 0.18 & -0.11 & 0.136 & 0.012 \\
\hline $\begin{array}{l}\text { Step } 3 \\
\text { Extraversion }\end{array}$ & 0.229 & 0.392 & 0.034 & & & & & & \\
\hline Agreeableness & $0.341 *$ & 0.305 & 0.07 & - & - & - & 0.006 & 0.26 & 0.001 \\
\hline Conscientiousness & - & - & - & - & - & - & - & - & - \\
\hline Neuroticism & -0.1 & 0.049 & 0.01 & -0.018 & 0.344 & 0.01 & - & - & - \\
\hline Openness to Experience & 0.149 & 0.64 & 0.015 & - & - & - & - & - & - \\
\hline
\end{tabular}

\footnotetext{
*. Correlation is significant at the 0.05 level (2-tailed).
}

**. Correlation is significant at the 0.01 level (2-tailed)

It can be observed from results that the main effect of agreeableness with OCB was $(\beta=.26, p<.05)$ with overall variance explained $(R=.34)$ and the change in variance due to agreeableness $\left(\Delta R^{2}=.06, p<0.05\right)$. In mediation analysis after controlling for the mediator (idealism) this main effect decreased to $(\beta=.006, n s)$ with decreased overall variance up to $\left(R^{2}=.26\right)$ and remained change in variance accounted only $\left(\Delta R^{2}=.001, n s\right) .0 \%$ due to extraversion. While for the workplace deviance this mediation was not proved due to not fulfilling (Baron and Kenny, 1986) criteria of testing mediation. It can be observed from results that the main effect of agreeableness with interpersonal conflict was $(\beta=.49$, $p<.001)$ with overall variance explained $(R=.24)$ and the change in variance due to extraversion $\left(\Delta R^{2}=.20, p<0.01\right)$. In mediation analysis after controlling for mediator this main effect decreased to $(B=.34, p<0.05)$ with decreased overall variance up to $(R=.30)$ and remained change in variance accounted only $\left(\Delta R^{2}=.07, p<0.05\right)$. 7\% due to agreeableness.

It can be observed from results that the main effect of openness to experience with interpersonal conflict was ( $(=.24, p$ $<.05)$ with overall variance explained $(R=.31)$ and the change in variance due to extraversion $\left(\Delta R^{2}=.04, p<0.05\right)$. In mediation analysis after controlling for the mediator (relativism) this main effect decreased to $(B=.15$, ns) with decreased overall variance up to $(R=.64)$ and remained change in variance accounted only $\left(\Delta R^{2}=.01, n s\right) .1 \%$ due to openness to experience.

It can be observed from results that the main effect of neuroticism with interpersonal conflict was $(\beta=.18, p<.05)$ with overall variance explained $(R=.69)$ and the change in variance due to neuroticism $\left(\Delta R^{2}=.04, p<0.05\right)$. In mediation 
analysis after controlling for the mediator (relativism) this main effect decreased to $(B=-.10, n s)$ with decreased overall variance up to $\left(R^{2}=.05\right)$ and remained change in variance accounted only $\left(\Delta R^{2}=.01, n s\right) .1 \%$ due to neuroticism. It can be observed from results that the main effect of neuroticism with workplace deviance was $(\beta=.16, p<.01)$ with overall variance explained $(R=.15)$ and the change in variance due to neuroticism $\left(\Delta R^{2}=.02, p<0.01\right)$. In mediation analysis after controlling for the mediator (relativism) this main effect decreased $(\beta=-.02, n s)$ with decreased overall variance up to $(R=.34)$ and remained change in variance accounted only $\left(\Delta R^{2}=.00, n s\right) .0 \%$ due to neuroticism.

\section{Contribution to Theory and Future Research Directions}

This research has filled the gap in personality and ethical ideology literature (Ameer, 2017; Tsai, \& Tsai, 2017) based on ethics position theory providing ample room for future research. Incorporation of multiple theories in a single framework resulted in a new theoretical foundation for both domains of research (personality and ethical ideology). The analysis of outcomes such as OCB, workplace deviance, and interpersonal conflict with Big Five personality traits and empirical evidence from a collectivist cultural context added value in personality research. The results linking personality and outcomes are in line with the findings of Colbert et al. (2004), Cebeci, (2016), and Tsai, and Tsai, (2017). The studies investigating such a group of outcomes in a single study is very rare in personality research. Specifically, in the eastern context. The second major advancement in literature is conceptualizing a theoretical linkage between Big Five personality traits and ethical ideology dimensions of idealism and relativism. This study results advanced the literature by providing ample support to proposed mediated links.

\section{Contribution to Practice}

Managers in the field are comfortably using the Big Five personality trait to predict the performance at the time of selection and placement decisions. This study finding confirmed that Big Five personality dimensions were significantly related to study outcomes. In this scenario, if the managers wish to encourage extra-role behaviours at workplace extraversion, conscientiousness and agreeableness significantly predicted OCB in this study. Managers may use these findings in selection and placement decisions.

The findings of this study may be used in diverse academic and field setting to help the managers, practitioners, and employees in clearly understanding the mechanism through which individual and group outcomes are determined by each personality type. How ethical ideology of each individual plays a role in determining the positive and negative behaviours exhibited at the workplace.

\section{CONCLUSION}

The growth of personality research in the last four decades has provided scholars and practitioners with a comprehensive view of the workplace that how personality is an important factor in the workplace. The role of ethics in the workplace can never be ignored but how ethical decision making becomes instrumental to predict behaviours determined by personality types was the area that received little attention in both personality and ethics literature. This study attempted to bridge this gap by theorizing and testing a comprehensive framework using the constructs from both fields. This research advanced the literature on ethical ideology and Big Five personality traits by incorporating the theories from both domains of research. This study investigated several new relationships to contribute to the literature which may be used in the future to further advance the field. Not only new conceptualizations are theorized but study results provided good support for those conceptualizations. In organizational behaviour research, this comprehensive framework contributed to enhanced levels of integration between organizational environment and personal characteristics and attributes.

This result provided the room to test ethics position theory on the data from a collectivist cultural context. Using a longitudinal study design to determine the causality of predicted relationships made this research an important contribution to the body of knowledge. Not only this research responded to the previous calls for investigations but it also advanced the literature on certain aspects of research and practice. This study also provided a basis for future research and opened a new horizon of research for the scholars in the field. Overall based on the rigorous procedure and methodology as well as reliability and validity of the finding it can be concluded that this is a significant piece of research contribution to the literature, theory and practice.

\section{LIMITATION AND STUDY FORWARD}

Some of the limitations are present in this study which must be addressed by future researchers. This study took place in Pakistan and Thailand. Future studies may replicate in a different context or different sample to further validate the findings of this research regarding these insignificant relationships. This study did not find support for some of the proposed relationships; a future study is recommended for an in-depth analysis of ethical ideology linkages with OCB to determine whether individuals with both ethical ideologies dimensions' exhibit OCB or only one of them is a significant predictor of OCB. Future research investigating the role of possible moderators as a buffering mechanism can be a good contribution to theory and practice. 


\section{ACKNOWLEDGEMENT}

The authors did not receive any financial or non-financial support from any organization to carry out this study.

\section{AUTHORS CONTRIBUTION}

All authors made useful contributions. Dr. Rudsada Kaewsaeng-on worked on drafting the initial write-up, Dr. Tariq Iqbal Khan collected data from Thailand and Abdul Zahid Khan collected data from Pakistan. All authors worked collectively on data analysis and the formulation of results.

\section{REFERENCES}

1. Abbas, M., Raja, U., Darr, W., \&Bouckenooghe, D. (2012). Combined Effects of perceived Politics and Psychological Capital on Job Satisfaction, Turnover Intentions, and Performance. Journal of Management. https://doi.org/10.1177/0149206312455243

2. Ameer, N. (2017). Impact of organizational culture on employee performance and Organizational Citizenship Behavior (OCB).International Journal of Business and Administrative Studies, 3(5), 183-196. https://doi.org/10.20469/ijbas.3.10004-5

3. Antara, P. M., Musa, R., Hassan, F. (2016). Theorising attitude towards Islamic financing adoption in an integrative model of behavioural prediction: A proposed conceptual framework. Journal of Administrative and Business Studies, 1(1), 35-41. https://doi.org/10.20474/jabs-1.1.6

4. Ashton, M. C., \& Lee, K. (2001).A theoretical basis for the major dimensions of personality.European Journal of Personality, 15(5), 327-353. https://doi.org/10.1002/per.417

5. Baron, R. M., \& Kenny, D. A. (1986). The moderator-mediator variable distinction in social psychological research: Conceptual, strategic, and statistical considerations. Journal of Personality and Social Psychology, 51(6), 1173. https://doi.org/10.1037/0022-3514.51.6.1173

6. Barrick, M. R., \& Mount, M. K. (1991). The big five personality dimensions and job performance: a metaanalysis. Personnel Psychology, 44(1), 1-26. https://doi.org/10.1111/j.1744-6570.1991.tb00688.x

7. Barrick, M. R., Parks, L., \& Mount, M. K. (2005).Self Monitoring as a Moderator of the Relationships between Personality Traits and Performance.PersonnelPsychology, 58(3), 745-767. https://doi.org/10.1111/j.17446570.2005.00716.x

8. Berings, D., De Fruyt, F., \&Bouwen, R. (2004). Work values and personality traits as predictors of enterprising and social vocational interests. Personality and individual differences, 36(2), 349-364. https://doi.org/10.1016/S0191-8869(03)00101-6

9. Bizon, W. (2016).Stimulating entrepreneurship by introducing behavioural incentives, propensity to use financial instruments in the context of decision-makers' characteristics and their financial knowledge in Polish SMEs.Journal of Administrative and Business Studies, 2(6), 270-279. https://doi.org/10.20474/jabs-2.6.2

10. Cebeci, I. (2016). Istanbul's position as a financial centre: An empirical analysis. International Journal of Business and Economic Affairs, 1(1), 1-5. https://doi.org/10.24088/IJBEA-2016-11001

11. Chang, C.-H., Rosen, C. C., \& Levy, P. E. (2009). The relationship between perceptions of organizational politics and employee attitudes, strain, and behaviour: A meta-analytic examination. Academy of Management Journal, 52(4), 779-801. https://doi.org/10.5465/amj.2009.43670894

12. Colbert, A. E., Mount, M. K., Harter, J. K., Witt, L., \&Barrick, M. R. (2004). Interactive effects of personality and perceptions of the work situation on workplace deviance. Journal of Applied Psychology, 89(4), 599. https://doi.org/10.1037/0021-9010.89.4.599

13. Costa Jr, P. T., \&Widiger, T. A. (1994).Personality disorders and the five-factor model of personality: American Psychological Association. https://doi.org/10.1037/10140-000

14. Costa, P. T., \& McCrae, R. R. (1992). Professional manual: revised NEO personality inventory (NEO-PI-R) and NEO five-factor inventory (NEO-FFI). Odessa, FL: Psychological Assessment Resources.

15. Epstein, S., \& O'Brien, E. J. (1985). The person-situation debate in historical and current perspective. Psychological Bulletin, 98(3), 513. https://doi.org/10.1037/0033-2909.98.3.513

16. Finn, D. W., Chonko, L. B., \& Hunt, S. D. (1988). Ethical problems in public accounting: the view from the top. Journal of Business Ethics, 7(8), 605-615. https://doi.org/10.1007/BF00382793

17. Forsyth, D. R. (1980). A taxonomy of ethical ideologies. Journal of Personality and Social Psychology, 39(1), 175. https://doi.org/10.1037/0022-3514.39.1.175

18. Forsyth, D. R. (1992). Judging the morality of business practices: The influence of personal moral philosophies. Journal of Business Ethics, 11(5-6), 461-470. https://doi.org/10.1007/BF00870557

19. Gilligan, C. (1982). In a different voice: Psychological theory and women development (Vol. 326). Harvard University Press.

20. Goldberg, J. (2000). Decoding of sorting signals by coatomer through a GTPase switch in the COPI coat complex. Cell, 100(6), 671-679. https://doi.org/10.1016/S0092-8674(00)80703-5

21. Goldberg, L. R. (1992). The development of markers for the Big-Five factor structure. Psychological assessment, 4(1), 26. https://doi.org/10.1037/1040-3590.4.1.26

22. Graziano, W. G., \& Eisenberg, N. (1997). Agreeableness: A dimension of personality. In Handbook of 
personality psychology (pp. 795-824).Academic Press. https://doi.org/10.1016/B978-012134645-4/50031-7

23. Grover, S. A., Coupal, L., Zowall, H., Alexander, C. M., Weiss, T. W., \& Gomes, D.R. (2001). How costeffective is the treatment of dyslipidemia in patients with diabetes but without cardiovascular disease? Diabetes Care, 24(1), 45-50. https://doi.org/10.2337/diacare.24.1.45

24. Haq, I. U., Ramay, M. I., Rehman, M. A. U., \& Jam, F. A. (2010). Big five personality and perceived customer relationship management. Research Journal ofInternational Studies, 15, 37-45.

25. Henle, C. A., Giacalone, R. A., \&Jurkiewicz, C. L. (2005). The role of ethical ideology in workplace deviance. Journal of Business Ethics, 56(3), 219-230. https://doi.org/10.1007/s10551-004-2779-8

26. Hofsted, G. (1980). Motivation, leadership and organization Do American theories applied abroad. Organizational Dynamics, 9, 42-63. https://doi.org/10.1016/0090-2616(80)90013-3

27. Hofstee, W. K., De Raad, B., \& Goldberg, L. R. (1992). Integration of the big five and circumplex approaches to trait structure. Journal of Personality and Social Psychology, 63(1), 146. https://doi.org/10.1037/0022$\underline{3514.63 .1 .146}$

28. Hough, L. M. (1992). The' Big Five'personality variables--construct confusion: Description versus prediction. Human performance, 5(1-2), 139-155. https://doi.org/10.1080/08959285.1992.9667929

29. Hough, L. M., Eaton, N. K., Dunnette, M. D., Kamp, J. D., \&McCloy, R. A. (1990). Criterion-related validities of personality constructs and the effect of response distortion on those validities. Journal of applied psychology, 75(5), 581. https://doi.org/10.1037/0021-9010.75.5.581

30. John, O. P., \&Srivastava, S. (1999). The Big Five trait taxonomy: History, measurement, and theoretical perspectives. Handbook of Personality: Theory and Research, 2(1999), 102-138.

31. Judge, T. A., Heller, D., \& Mount, M. K. (2002). Five-factor model of personality and job satisfaction: a meta-analysis. Journal of Applied Psychology, 87(3), 530.

32. Kohlberg, L. (1984). Essays on moral development. Volume II. The psychology of moral development.Harper and Row, New York.

33. Kohlberg, L., Levine, C., \& Hewer, A. (1983).Moral stages: A current formulation and a response to critics.

34. Lannu, J. E., \&Nobleza, M. F. L. (2017). The impact of competitiveness on the employability of Philippines industrial designers: Streamlining the program with the international market. International Journal of Business and Administrative Studies, 3(1), 30-36. https://doi.org/10.20469/ijbas.3.10005-1

35. Mobley, W. H., Griffeth, R. W., Hand, H. H., \&Meglino, B. M. (1979). Review and conceptual analysis of the employee turnover process. Psychological Bulletin, 86(3), 493.

36. Morgeson, F. P., Reider, M. H., \& Campion, M. A. (2005).Selecting individuals in team settings: The importance of social skills, personality characteristics, and teamwork knowledge. Personnel Psychology, 58(3), 583-611. https://doi.org/10.1111/j.1744-6570.2005.655.x

37. Mount, M. K., Barrick, M. R., \& Strauss, J. P. (1999). The joint relationship of conscientiousness and ability with performance: Test of the interaction hypothesis. Journal of Management, 25(5), 707-721. https://doi.org/10.1177/014920639902500505

38. Ones, D. S., Viswesvaran, C., \& Schmidt, F. L. (2003). Personality and absenteeism: a meta-analysis of integrity tests. European Journal of Personality, 17(S1), S19-S38. https://doi.org/10.1002/per.487

39. Organ, D. W. (1988). Organizational citizenship behaviour: The good soldier syndrome. Lexington Books/DC Heath and Com.

40. Organ, D. W., \& Ryan, K. (1995). A meta-analytic review of attitudinal and dispositional predictors of organizational citizenship behaviour. Personnel Psychology, 48(4), 775-802. https://doi.org/10.1111/j.17446570.1995.tb01781.x

41. Penley, J. A., \&Tomaka, J. (2002). Associations among the Big Five, emotional responses, and coping with acute stress. Personality and individual differences, 32(7), 1215-1228. https://doi.org/10.1016/S01918869(01)00087-3

42. Raja, U., \& Johns, G. (2010). The joint effects of personality and job scope on in-role performance, citizenship behaviours, and creativity. Human Relations, 63(7), 981-1005. https://doi.org/10.1177/0018726709349863

43. Raja, U., Johns, G., \&Ntalianis, F. (2004).The impact of personality on psychological contracts.Academy of Management Journal, 47(3), 350-367. https://doi.org/10.5465/20159586

44. Robinson, S. L., \& Bennett, R. J. (1995). A typology of deviant workplace behaviours: A multidimensional scaling study. Academy of Management Journal, 38(2), 555-572. https://doi.org/10.2307/256693

45. Rogosch, F. A., \&Cicchetti, D. (2004). Child maltreatment and emergent personality organization: Perspectives from the five-factor model. Journal of abnormal child Psychology, 32(2), 123-145. https://doi.org/10.1023/B:JACP.0000019766.47625.40

46. Sackett, P. R., \&Wanek, J. E. (1996). New developments in the use of measures of honesty integrity, conscientiousness, dependability trustworthiness, and reliability for personnel selection. Personnel Psychology, 49(4), 787-829. https://doi.org/10.1111/j.1744-6570.1996.tb02450.x

47. Salgado, J. F. (2002). The Big Five personality dimensions and counterproductive behaviours. International Journal of Selection and Assessment, 10(1-2), 117-125. https://doi.org/10.1111/1468-2389.00198

48. Spector, P. E., \& Fox, S. (2002). An emotion-centred model of voluntary work behaviour: Some parallels 
between counterproductive work behaviour and organizational citizenship behaviour. Human Resource Management Review, 12(2), 269-292. https://doi.org/10.1016/S1053-4822(02)00049-9

49. Spector, P. E., \&Jex, S. M. (1998). Development of four self-report measures of job stressors and strain: Interpersonal Conflict at Work Scale, Organizational Constraints Scale, Quantitative Workload Inventory, and Physical Symptoms Inventory. Journal of Occupational Health Psychology, 3(4), 356. https://doi.org/10.1037/1076-8998.3.4.356

50. Trapnell, P. D., \& Wiggins, J. S. (1990). Extension of the Interpersonal Adjective Scales to include the Big Five dimensions of personality. Journal of Personality and Social Psychology, 59(4), 781. https://doi.org/10.1037/0022-3514.59.4.781

51. Tsai, M. S., \& Tsai M. C. (2017). The influence of loyalty, participation and obedience on organizational citizenship behaviour. International Journal of Business and Economic Affairs, 2(1), 67-76. https://doi.org/10.24088/IJBEA-2017-21009

52. Tsui, A. S., Nifadkar, S. S., \&Ou, A. Y. (2007). Cross-national, cross-cultural organizational behaviour research: Advances, gaps, and recommendations. Journal of Management, 33(3): 426-478. https://doi.org/10.1177/0149206307300818

53. Watson, D., \& Clark, L. A. (1984). Negative affectivity: the disposition to experience aversive emotional states. Psychological Bulletin, 96(3), 465. https://doi.org/10.1037/0033-2909.96.3.465

54. Watson, D., \& Clark, L. A. (1997).Extraversion and its positive emotional core. https://doi.org/10.1016/B978$\underline{012134645-4 / 50030-5}$

55. Wiggins, J. S. (1991). Agency and communion as conceptual coordinates for the understanding and measurement of interpersonal behaviour.

56. Wiggins, J. S., \&Trapnell, P. D. (1997). Personality structure: The return of the big five. https://doi.org/10.1016/B978-012134645-4/50029-9

57. Williams, L. J., \& Anderson, S. E. (1991). Job satisfaction and organizational commitment as predictors of organizational citizenship and in-role behaviours. Journal of Management, 17(3), 601-617. https://doi.org/10.1177/014920639101700305

58. Witt, L. A., Kacmar, K. M., Carlson, D. S., \&Zivnuska, S. (2002). Interactive effects of personality and organizational politics on contextual performance. Journal of Organizational Behavior: The International Journal of Industrial, Occupational and Organizational Psychology and Behavior,23(8), 911-926. https://doi.org/10.1002/job.172

59. Witt, L., Burke, L. A., Barrick, M. A., \& Mount, M. K. (2002). The interactive effects of conscientiousness and agreeableness on job performance. Journal of Applied Psychology, 87(1), 164. https://doi.org/10.1037/00219010.87.1.164

60. Zhang, L.-F.(2002). Thinking styles and the big five personality traits. Educational Psychology, 22(1), 17-31. https://doi.org/10.1080/01443410120101224 